The Canadian Mineralogist

Vol. 38, pp. 657-668 (2000)

\title{
THE CRYSTAL STRUCTURE OF FRANZINITE, THE TEN-LAYER MINERAL OF THE CANCRINITE GROUP
}

\author{
PAOLO BALLIRANO \\ Dipartimento di Scienze della Terra, Università di Roma “La Sapienza”, P.le A. Moro 5, I-00185 Roma, Italia
}

ELENA BONACCORSI ${ }^{\S}$

Dipartimento di Scienze della Terra, Università di Pisa, V. Santa Maria 53, I-56126, Pisa, Italia

ADRIANA MARAS

Dipartimento di Scienze della Terra, Università di Roma "La Sapienza”, P.le A. Moro 5, I-00185 Roma, Italia

STEFANO MERLINO

Dipartimento di Scienze della Terra, Università di Pisa, V. Santa Maria 53, I-56126, Pisa, Italia

\begin{abstract}
Franzinite, ideally $\left[(\mathrm{Na}, \mathrm{K})_{30} \mathrm{Ca}_{10}\right]\left[\mathrm{Si}_{30} \mathrm{Al}_{30} \mathrm{O}_{120}\right]\left(\mathrm{SO}_{4}\right)_{10} \bullet 2 \mathrm{H}_{2} \mathrm{O}$, a feldspathoid belonging to the cancrinite group, has a tenlayer stacking sequence. Its structure was solved in the space group $P 321$ to an $R$ value of $5.96 \%$. Cell parameters are $a 12.916(1)$, c 26.543(3) A. The framework, characterized by the stacking sequence $A B C A B A C A B C$, contains regular alternations of two "cancrinite" and two "sodalite" cages along $\left[\begin{array}{lll}0 & 0 & z\end{array}\right]$, and of two "sodalite" and one "losod" cages along $\left[\begin{array}{lll}2 / 3 & 1 / 3 \\ z\end{array}\right]$ and $\left[\begin{array}{lll}1 / 3 & 2 / 3 & z\end{array}\right]$. The $\mathrm{Si}$ :Al ratio is equal to 1 , and the framework has a perfectly ordered $\mathrm{Si}, \mathrm{Al}$ distribution, as was found in liottite and afghanite, the 6- and 8-layer cancrinite-like minerals, respectively. The cages host a complex distribution of extra-framework cations (Ca, $\mathrm{Na}$, $\mathrm{K}),\left(\mathrm{SO}_{4}\right)^{2-}$ anions, and $\mathrm{H}_{2} \mathrm{O}$ molecules. The "losod" cage contains two sulfate groups aligned along $z$ and separated by a triplet of cations. Two additional triplets of cations are located around the two sulfate groups. The two bases of the cage are occupied by calcium atoms, which make favorable bond-distances with the apical atoms of oxygen of the $\mathrm{SO}_{4}$ tetrahedra within the cage. The two "cancrinite" cages share a common base and contain a segment of the ...Na- $\mathrm{H}_{2} \mathrm{O} \ldots \mathrm{Na}-\mathrm{H}_{2} \mathrm{O} \ldots$. chain, which is a characteristic feature of the cancrinite, vishnevite, and pitiglianoite structures. The "sodalite" cages host one sulfate group that is always disordered and displaced from the three-fold axis. The (Ca, K, Na) cations are distributed among various split sites, each one with partial occupancy, showing marked similarity with the "sodalite" cages of the $\left(\mathrm{SO}_{4}\right)^{2-}$ - and $\mathrm{S}^{2-}$-bearing minerals with sodalitetype structure.
\end{abstract}

Keywords: franzinite, cancrinite group, sodalite group, feldspathoids, structure determination, IR spectroscopy, stacking sequences.

\section{SOMMAIRE}

La franzinite, un feldspathoïde dont la composition idéale est $\left[(\mathrm{Na}, \mathrm{K})_{30} \mathrm{Ca}_{10}\right]\left[\mathrm{Si}_{30} \mathrm{Al}_{30} \mathrm{O}_{120}\right]\left(\mathrm{SO}_{4}\right)_{10} \bullet 2 \mathrm{H}_{2} \mathrm{O}$, fait partie du groupe de la cancrinite, et possède une période d'empilement de dix couches. Nous avons résolu sa structure dans le groupe spatial $P 321$ jusqu'à un résidu $R$ de $5.96 \%$. Les paramètres réticulaires sont $a 12.916(1)$ et $c$ 26.543(3) Å. La trame, dont l'empilement répond à la séquence $A B C A B A C A B C$, contient des alternances régulières de deux cages de type "cancrinite" et deux cages de type

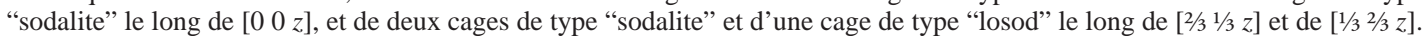
Le rapport Si:Al est égal à 1, et la trame possède un degré d'ordre parfait, tout comme c'est le cas pour la liottite et l'afghanite, les membres du groupe de la cancrinite à six et à huit couches, respectivement. Les couches renferment un assemblage de cations ne formant pas partie de la trame $(\mathrm{Ca}, \mathrm{Na}, \mathrm{K})$, des anions $\left(\mathrm{SO}_{4}\right)^{2-}$ et des molécules de $\mathrm{H}_{2} \mathrm{O}$, tous distribués de façon très complexe. La cage "losod" contient deux groupes sulfate alignés le long de $z$ et séparés par un triplet de cations. Deux triplets additionnels de cations sont situés autour des deux groupes de sulfate. Les deux bases de la cage sont le site d'atomes de calcium, disposés à une distance favorable des atomes apicaux d'oxygène des tétraèdres de $\mathrm{SO}_{4}$ à l'intérieur de la cage. Les deux cages de type "cancrinite" partagent une base commune et contiennent un segment de la chaîne ... $\mathrm{Na}-\mathrm{H}_{2} \mathrm{O} \ldots \mathrm{Na}-\mathrm{H}_{2} \mathrm{O} \ldots$..., attribut des structures

$\S \quad$ E-mail address: elena@dst.unipi.it 
de la cancrinite, la vishnevite et la pitiglianoïte. Les cages de type "sodalite" cages contiennent un groupe sulfate invariablement désordonné, et déplacé de l'axe de rotation trois. Les cations ( $\mathrm{Ca}, \mathrm{K}, \mathrm{Na})$ sont distribués sur plusieurs sous-sites, chacun étant incomplètement rempli, et ressemblant ainsi aux cages de type "sodalite" des minéraux sulfatés et sulfurés possédant la structure de la sodalite.

(Traduit par la Rédaction)

Mots-clés: franzinite, groupe de la cancrinite, groupe de la sodalite, feldspathoïde, détermination de la structure, spectroscopie infra-rouge, séquences d'empilement.

\section{INTRODUCTION}

A broad structural investigation of the minerals pertaining to the cancrinite group has recently been undertaken. These minerals are trigonal and hexagonal feldspathoids whose framework is built by the stacking along [001] of layers made of six-membered rings of $T \mathrm{O}_{4}$ tetrahedra $(T: \mathrm{Si}, \mathrm{Al})$. The resulting topologies show cages and open channels that are filled by interstitial cations and anions. Approximately fourteen phases pertaining to this group are known, with two to twentyeight layers per unit cell, corresponding to $c$ parameters of 5 to $74 \AA$. For a detailed discussion of the features of the various members of the cancrinite family, see for example Ballirano et al. (1996a).

Franzinite was found in ejectum collected near Pitigliano, a well-known mineral-collecting locality of Tuscany, Italy (Merlino \& Mellini 1976, Merlino \& Orlandi 1977). The ejectum, mainly composed of diopside and vesuvianite, is the result of a metasomatic process involving a trachytic magma and the host carbonate-rich metasedimentary rocks. From Weissenberg and precession photographs, the Laue symmetry $\overline{3} m 1$ was determined, as well as the cell parameters $a \approx 12.9$, $c \approx 26.6 \AA$. The $c$ cell parameter pointed to a 10-layer stacking sequence. All attempts to solve the structure were unsuccessful, as $R$ indices were never better than $25 \%$. A stacking sequence $A B C A B C B A C B$ was proposed by Merlino (1976); he suggested that the $C$ layer in the sixth position was disordered and replaced periodically by an $A$ layer with a one-third statistical probability. Rinaldi \& Wenk (1979) confirmed the occurrence of stacking faults by means of both electron diffraction and transmission electron microscopy. They observed the presence of diffuse and weak satellite reflections, considered to be indicative of an incommensurate superstructure. This superstructure was ascribed to distortions of the framework due to ordering of extraframework anions and cations or to long-range $\mathrm{Si}$, $\mathrm{Al}$ order.

Samples of franzinite were subsequently reported from other localities of the Roman perpotassic province (Leoni et al. 1979, Franceschini \& Orlandi 1989, Ballirano et al 1996b). Important differences in chemical composition have been reported among the samples, especially with respect to the $\mathrm{CO}_{2}$ and $\mathrm{H}_{2} \mathrm{O}$ content, as discussed by Ballirano et al. (1996b).
The aims of this work are to establish the correct sequence of the layers in franzinite, and to check whether perfect $\mathrm{Si}, \mathrm{Al}$ order occurs in franzinite as the other phases of this family (e.g., davyne, liottite, afghanite).

\section{EXPERIMENTAL}

A crystal of colorless and transparent franzinite (approximately $0.2 \times 0.2 \times 0.2 \mathrm{~mm}$ ) was selected from a sample labeled as MMUR (Mineralogical Museum of the University of Roma) 24340, and used to collect the $\mathrm{X}$-ray data. The hand specimen is an ejectum mainly composed of diopside and tuscanite, which was collected near Sacrofano, in Latium, Italy.

The chemical data (Ballirano et al. 1996b), obtained on a CAMECA SX-50 electron microprobe, point to the empirical formula $\left(\mathrm{Na}_{20.5} \mathrm{~K}_{6.7} \mathrm{Ca}_{11.7}\right)\left(\mathrm{Si}_{29.8} \mathrm{Al}_{30.2}\right)$ $\mathrm{O}_{119.7}\left(\mathrm{SO}_{4}\right)_{10.0} \mathrm{Cl}_{0.3} \mathrm{~F}_{0.1}$.

The infrared (IR) spectrum of franzinite (Ballirano et al. 1996b) shows only relatively weak absorption bands in the $4000-3000 \mathrm{~cm}^{-1}$ range, typical of the $\mathrm{O}-\mathrm{H}$ stretching vibrations, in contrast with the presence of large amounts of $\mathrm{H}_{2} \mathrm{O}$ reported in the literature data. In order to investigate with more accuracy the 4000-3000 $\mathrm{cm}^{-1}$ range, we performed new IR analyses. Data were collected on a Perkin Elmer FT-IR 2000, averaging 48 scans with a nominal resolution of $4 \mathrm{~cm}^{-1}$, using the conventional $\mathrm{KBr}$ pellet technique. A $\mathrm{KBr}$ pellet with a franzinite: $\mathrm{KBr}$ ratio of 5:200 (instead of the commonly used 2:200 ratio) was prepared, with the aim to improve the intensity of the relatively weak absorption bands associated with the $\mathrm{O}-\mathrm{H}$ stretching vibrations. The IR spectra are reported in Figure 1. The analyses were repeated after heating the pellet in an oven at $80^{\circ} \mathrm{C}$ in order to remove the humidity adsorbed by both $\mathrm{KBr}$ and sample: the broad band, initially located between 3700 and $3000 \mathrm{~cm}^{-1}$, became narrower, and a peak appears at around $3590 \mathrm{~cm}^{-1}$ as well as a small hump centered at $3450 \mathrm{~cm}^{-1}$. These features seem to indicate the presence of a disordered distribution of $\mathrm{H}_{2} \mathrm{O}$ molecules. In fact, the IR spectrum of carbonate-dominant cancrinite (Ballirano et al. 1995) shows two well-defined peaks located at 3607 and $3539 \mathrm{~cm}^{-1}$, which correspond, according to the plot of Nakamoto et al. (1955), to $(\mathrm{Si}, \mathrm{Al}) \mathrm{O} \ldots \mathrm{OH}_{2}$ distances of 3.1 and $3.0 \AA$, in excellent agreement with the known refinements of the structure 


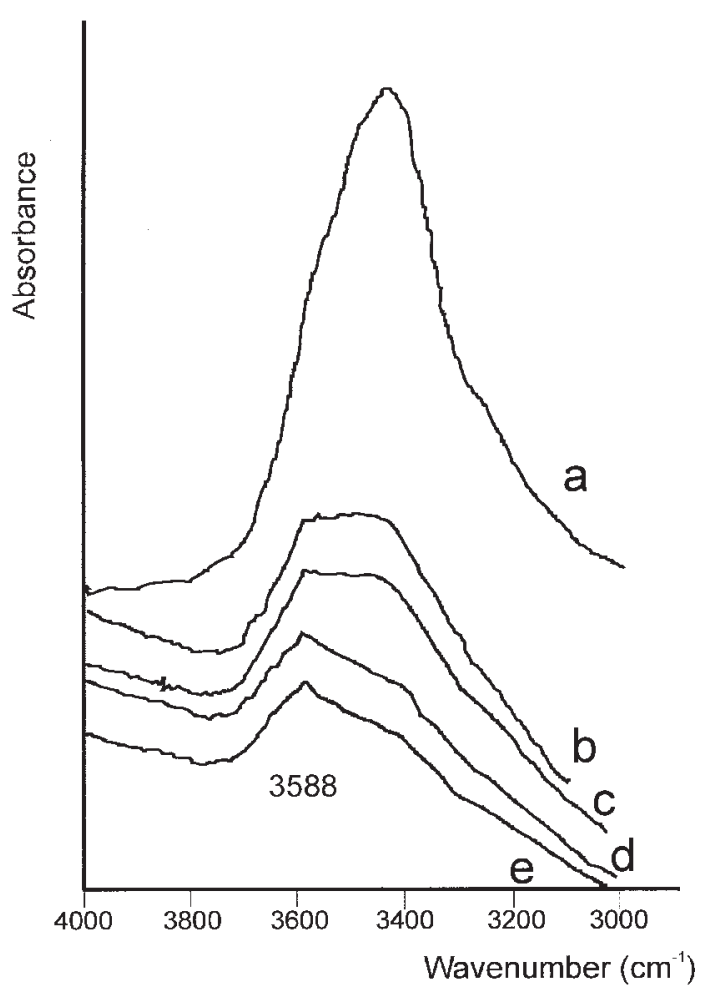

FIG. 1. IR spectra of franzinite MMUR 24340 (4000$3000 \mathrm{~cm}^{-1}$ range): a) immediately after the preparation of the pellet, b) after $1 \mathrm{~h}$ at $80^{\circ} \mathrm{C}$, c) after $3 \mathrm{~h}$ at $80^{\circ} \mathrm{C}$, d) after 4 days at $80^{\circ} \mathrm{C}$, and e) after 10 days at $80^{\circ} \mathrm{C}$. The pellet was stored in an oven in order to remove the adsorbed humidity.

of this mineral (Jarchow 1965, Smolin et al. 1981, Emiraliev \& Yamzin 1982, Grundy \& Hassan 1982).

Information on the X-ray single-crystal data collection are summarized in Table 1.

\section{Structure Determination and Refinement}

The stacking along [001] of layers made of six-membered rings of $\mathrm{TO}_{4}$ tetrahedra may be discussed following the procedure first developed by Zhdanov (1945) for the close-packed stacking of layers of equal spheres. Sixteen different stacking sequences are possible for a ten-layer repeat (Patterson \& Kasper 1959). Five sequences present $P \overline{3} \mathrm{~m} 1$ symmetry: two of them, which may be denoted (8)(2) and (6)1(2)1 according to Zhdanov's notation (Patterson \& Kasper 1959), present the center of inversion at the origin in the center of a hexagonal ring; the other three sequences, (7)1(1)1, (5)1(3)1 and (3)21(1)12, present the center of symmetry at the origin not in the center of a hexagonal ring, but in an "octahedral void" between successive layers (Patterson \& Kasper 1959). Finally, two more sequences
TAIBLE I MTSCEI I ANLOUS DATA FOR TIE STRUCTURAL RELINEMENT OF FRANZINITE.

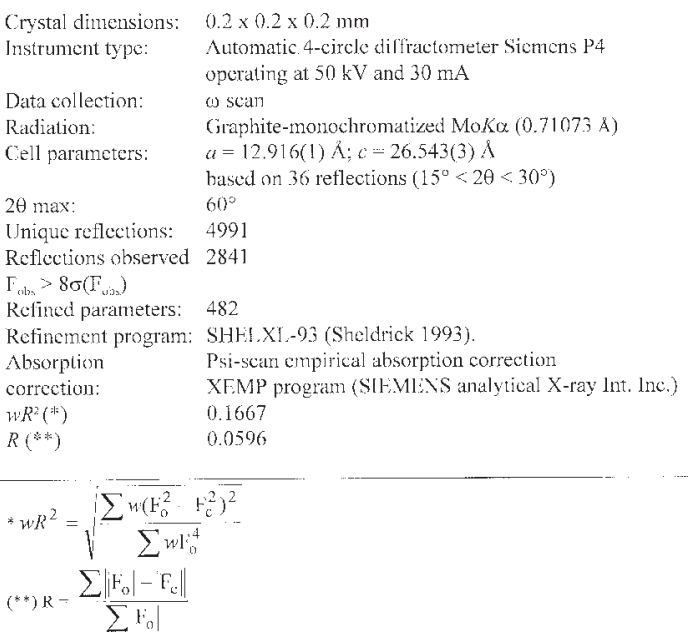

are possible, corresponding to $P \overline{3} m 1$ symmetry, 4312 and 321211. We assumed, as indicated by the crystal structure of afghanite, the eight-layer member of the group, that the operator is in the center of a hexagonal ring, and we tested the two possible sequences, (8)(2) and (6)1(2)1: the comparison of the observed and calculated structure-factors clearly indicates that the correct sequence is (8)(2). The space-group symmetry $P \overline{3} \mathrm{~m} 1$ does not allow an ordering of silicon and aluminum in the framework of tetrahedra. In keeping with the chemical composition of franzinite (Si:Al ratio of $1: 1$ ), and with the results of our recent refinements of the structures of liottite and afghanite (Ballirano et al. 1996a, 1997), we assumed an ordered distribution of the tetrahedrally coordinated cations in the space group $P 321$, the maximum-order subgroup of $P \overline{3} \mathrm{~m} 1$ allowing such distribution. The structure was completed by alternating difference Fourier maps and refinement cycles; the interpretation of the Fourier maps was made difficult by partial occupancies in the cationic sites, possible substitution involving $\mathrm{Ca}-\mathrm{Na}-\mathrm{K}$, as well as the disordered distribution of sulfate groups. We have labeled as " $A$ " the cationic sites in the center of the bases of the various cages, and " $M$ " the cationic sites within the cages. During the first cycles of the refinement, strong maxima were identified in the difference-Fourier maps in positions expected for both $\mathrm{S}$ and $\mathrm{Ca}$ atoms, according to the model proposed by Ballirano et al. (1996b). However, a few of these $\mathrm{Ca}$ atoms are disordered over two or three sites (A3-A3a-A3b; $A 4-A 4 \mathrm{a} ; A 6-A 6 \mathrm{a})$. Each set of split sites does not show a full occupancy, this fact being attributed to partial substitution of $\mathrm{Ca}$ with $\mathrm{Na}$. The displacement parameters of the two sulfur atoms located inside the "losod" cage (S4 and S5) are 
small and comparable; the sulfur atoms located inside the "sodalite" cages (S1, S2, and S3) have high and similar displacement-parameters. Following the procedure used in the structure refinement of liottite (Ballirano et al. 1996a) and afghanite (Ballirano et al. 1997), we displaced the S1, S2, and S3 sulfur atoms slightly from the three-fold axis. Further maxima were attributed to cations and to oxygen atoms pertaining to the sulfate groups. The occupancies of the oxygen sites were fixed as imposed by the correct geometry of the $\mathrm{SO}_{4}$ tetrahedra, as explained below. The distribution of the cations is extremely complex, with multiple splitting of the cationic sites $M(M 1-M 1 \mathrm{a} ; M 5-M 5 \mathrm{a}-M 5 \mathrm{~b}-M 5 \mathrm{c} ; M 6-$ $M 6 \mathrm{a}-M 6 \mathrm{~b}-M 6 \mathrm{c})$. The same anisotropic-displacement parameters have been refined for each set of split cation-sites. The corresponding occupancies were refined during the isotropic refinement and subsequently kept unchanged during the anisotropic refinement. Following the procedure described in the previous works on liottite and afghanite (Ballirano et al. 1996a, 1997), we refined the occupancies of the cation sites $M$ and $A$ in terms of the scattering power of Ca; successively, we calculated the actual cationic content as percentages of $\mathrm{Na}$ and $(\mathrm{K}, \mathrm{Ca})$ cations, assuming the full occupancy of each set of split sites.

The "cancrinite" cages show two relatively small maxima in electron density, $W$ and $A 2$, in positions expected for an anion and for a cation, respectively. According to the results of the chemical analysis and the IR data, it may be inferred that the $W$ site is prevalently occupied by $\mathrm{H}_{2} \mathrm{O}$ molecules, partially substituted by 0.3 atoms of $\mathrm{Cl}$ and 0.1 atoms of $\mathrm{F}$. As regards the $A 2$ site, the very high displacement-parameter obtained using the scattering power of $\mathrm{Ca}$ indicates that most probably it is occupied by $\mathrm{Na}$ atoms, forming a fragment of the ... Na$\mathrm{H}_{2} \mathrm{O} \ldots \mathrm{Na}-\mathrm{H}_{2} \mathrm{O}$... chain found in cancrinite, vishnevite and pitiglianoite.

The final $R$ agreement index was $5.96 \%$ for 2841 $\mathrm{F}_{\text {obs }}>8 \sigma\left(\mathrm{F}_{\text {obs }}\right)$ and 10.70 for all 4991 data; the $w R^{2}$ factor was $16.67 \%$ for $2841 \mathrm{~F}_{\text {obs }}>8 \sigma\left(\mathrm{F}_{\text {obs }}\right)$ and $24.76 \%$ for all 4991 data. The number of refined parameters is 482 (Table 1). Positional parameters and equivalent displacement parameters are reported in Table 2; the bond distances between cations and oxygen atoms of the framework are listed in Table 3, whereas the bonds that involve the oxygen atoms of the sulfate groups within the different cages are reported under the corresponding figures. Table 4 shows the population of all the extraframework sites, based on the refined electron-density and on crystal-chemical considerations. A table of structure factors is available at a nominal charge from the Depository of Unpublished Data, CISTI, National Research Council of Canada, Ottawa, Ontario K1A 0S2, Canada.

The franzinite framework (Fig. 2) is composed of regular alternations of two "cancrinite" and two "sodalite" cages along $\left[\begin{array}{lll}0 & 0 & z\end{array}\right]$, and two "sodalite" and one "losod" cages along $[2 / 31 / 3 z]$ and $[1 / 32 / 3 z]$ (Fig. 3).
TABLF 2. FRACIIONAL COORDINATES AND ISOTROPIC OR EQUIVAIJNT DISPLACEMENT PARAMETERS FOR FRANZINITE

\begin{tabular}{|c|c|c|c|c|}
\hline Atom & $x$ & $y$ & $z$ & $U_{\mathrm{is},}$ or $U_{\mathrm{eq}}$ \\
\hline Si1 & $0.5834(3)$ & $0.6684(3)$ & $0.9018(2)$ & $0.0158(9)$ \\
\hline $\mathrm{Al}]$ & $0.4190(3)$ & $0.3332(3)$ & $0.0978(2)$ & $0.0135(9)$ \\
\hline $\mathrm{A} 12$ & $0.5866(4)$ & $0.6658(3)$ & $0.1963(2)$ & $0.019(1)$ \\
\hline $\mathrm{Si} 2$ & $0.4158(3)$ & $0.3323(3)$ & $0.8038(2)$ & $0.0121(9)$ \\
\hline A13 & $0.5927(3)$ & $0.6770(3)$ & $0.6028(2)$ & $0.0120(9)$ \\
\hline $\mathrm{Si} 3$ & $0.4162(3)$ & $0.3365(3)$ & $0.3964(2)$ & $0.0139(9)$ \\
\hline Al4 & $0.7511(5)$ & $0.7511(5)$ & 0 & $0.018(2)$ \\
\hline $\mathrm{Si4}$ & $0.2472(5)$ & $0.2472(5)$ & 0 & $0.013(1)$ \\
\hline $\mathrm{Si} 5$ & $0.7486(3)$ & $0.7495(3)$ & $0.2976(2)$ & $0.0131(9)$ \\
\hline$\Delta 15$ & $0.2540(3)$ & $0.2515(3)$ & $0.7026(2)$ & $0.015(1)$ \\
\hline Si6 & $0.7485(4)$ & $0.7485(4)$ & 0.5 & $0.014(1)$ \\
\hline A16 & $0.2544(4)$ & $0.2544(4)$ & 0.5 & $0.012(1)$ \\
\hline$O 1$ & $0.4462(9)$ & $0.218(1)$ & $0.1051(3)$ & $0.065(3)$ \\
\hline 02 & $0.875(1)$ & $0.7478(5)$ & $0.2876(2)$ & $0.028(1)$ \\
\hline 03 & $0.2425(5)$ & $0.1159(8)$ & $0.5098(2)$ & $0.025(1)$ \\
\hline 04 & $0.322(1)$ & $0.0005(9)$ & $0.3468(5)$ & $0.028(3)$ \\
\hline 05 & $0.671(1)$ & $0.002(1)$ & $0.6482(5)$ & $0.025(2)$ \\
\hline 06 & $0.659(1)$ & $0.6760(9)$ & $0.5470(4)$ & $0.022(2)$ \\
\hline 07 & $0.353(1)$ & $0.3302(9)$ & $0.4504(4)$ & $0.022(2)$ \\
\hline 08 & $0.669(1)$ & $0.650(1)$ & $0.1495(6)$ & $0.049(4)$ \\
\hline O9 & $0.348(2)$ & $0.351(1)$ & $0.8495(7)$ & $0.060(5)$ \\
\hline 010 & $0.4501(5)$ & $0.2340(8)$ & $0.3901(2)$ & $0.022(1)$ \\
\hline 011 & $0.666(2)$ & $0.686(2)$ & $0.9481(6)$ & $0.072(6)$ \\
\hline 012 & $0.327(2)$ & $0.307(2)$ & $0.0468(7)$ & $0.084(8)$ \\
\hline 013 & $0.442(1)$ & $0.549(1)$ & $0.1995(2)$ & $0.035(2)$ \\
\hline 014 & $0.541(1)$ & $0.0786(5)$ & $0.3940(2)$ & $0.026(1)$ \\
\hline 015 & $0.656(1)$ & $0.673(1)$ & $0.2534(4)$ & $0.027(2)$ \\
\hline 016 & $0.344(1)$ & $0.320(1)$ & $0.7537(5)$ & $0.053(4)$ \\
\hline 017 & $0.888(1)$ & $0.7821(5)$ & $0.6994(2)$ & $0.030(1)$ \\
\hline 018 & $0.4275(7)$ & $0.220(1)$ & $0.8161(2)$ & $0.037(2)$ \\
\hline 019 & $0.9157(9)$ & $0.454(1)$ & $0.0863(3)$ & $0.065(3)$ \\
\hline$(020$ & $0.120(2)$ & $0.233(1)$ & $0.0106(3)$ & $0.074(3)$ \\
\hline S1 & $0.373(2)$ & $0.676(4)$ & $0.0546(3)$ & $0.064(7)$ \\
\hline$\$ 2$ & $0.343(3)$ & $0.706(1)$ & $0.7415(3)$ & $0.078(7)$ \\
\hline S3 & $0.025(2)$ & $0.023(2)$ & $0.1561(4)$ & $0.080(4)^{*}$ \\
\hline S4 & $1 / 3$ & $2 / 3$ & $0.3199(1)$ & $0.0293(7)$ \\
\hline $\mathrm{S5}$ & $1 / 3$ & $2 / 3$ & $0.4884(1)$ & $0.0241(6)$ \\
\hline$W$ & $0.009(8)$ & $0.039(4)$ & $0.604(1)$ & $0.11(1)^{*}$ \\
\hline Al & $2 / 3$ & $1 / 3$ & $0.8189(1)$ & $0.0370(7)$ \\
\hline $\mathrm{A} 2$ & 0 & 0 & $0.490(3)$ & $0.20(2)$ \\
\hline $\mathrm{A} 3$ & 0 & 0 & $0.7218(5)$ & $0.034(4)$ \\
\hline$\Lambda 3 a$ & 0 & 0 & $0.7477(9)$ & $0.034(4)$ \\
\hline $\mathrm{A} 3 \mathrm{~b}$ & 0 & 0 & $0.7009(9)$ & $0.034(4)$ \\
\hline $\mathrm{A4}$ & 0 & 0 & $0.0318(8)$ & $0.060(5)$ \\
\hline $\mathrm{A} 4 \mathrm{a}$ & 0 & 0 & 0 & $0.060(5)$ \\
\hline A5 & $2 / 3$ & $1 / 3$ & $0.3733(1)$ & $0.0276(6)$ \\
\hline$\wedge 6$ & $2 / 3$ & $1 / 3$ & $0.0635(4)$ & $0.051(2)$ \\
\hline$\wedge 6 \mathrm{a}$ & $2 / 3$ & $1 / 3$ & $0.1339(6)$ & $0.051(2)$ \\
\hline M1 & $0.503(1)$ & $0.503(1)$ & 0 & $0.047(2)$ \\
\hline Wla & $0.450(3)$ & $0.544(3)$ & $0.0150(5)$ & $0.047(2)$ \\
\hline $\mathrm{M} 2$ & $0.7815(3)$ & $0.5649(2)$ & $0.5960(1)$ & $0.0289(4)$ \\
\hline M3 & $0.4909(5)$ & $0.5140(5)$ & $0.3017(1)$ & $0.0396(7)$ \\
\hline M4 & $0.5015(4)$ & $0.5015(4)$ & 0.5 & $0.0284(6)$ \\
\hline M5 & $0.849(1)$ & $0.6967(9)$ & $0.8973(3)$ & $0.041(3)$ \\
\hline $\mathrm{M} 5 \mathrm{a}$ & $0.806(2)$ & $0.586(2)$ & $0.9164(6)$ & $0.041(3)$ \\
\hline M5b & $0.873(2)$ & $0.760(2)$ & $0.8870(6)$ & $0.041(3)$ \\
\hline M5c & $0.829(4)$ & $0.650(3)$ & $0.903(1)$ & $0.041(3)$ \\
\hline M6 & $0.834(1)$ & $0.6655(7)$ & $0.2001(2)$ & $0.034(2)$ \\
\hline M6a & $0.772(2)$ & $0.556(2)$ & $0.2169(5)$ & $0.034(2)$ \\
\hline M6b & $0.873(2)$ & $0.726(2)$ & $0.1849(6)$ & $0.034(2)$ \\
\hline M6c & $0.795(2)$ & $0.605(2)$ & $0.2139(7)$ & $0.034(2)$ \\
\hline OS1a & $0.617(5)$ & $0.32(2)$ & $0.9054(8)$ & $0.12(2)$ \\
\hline OS'1b & $0.375(4)$ & $0.603(4)$ & $0.0207(6)$ & $0.16(1)$ \\
\hline OS1c & $0.488(4)$ & $0.736(7)$ & $0.076(2)$ & $0.16(3)$ \\
\hline $\operatorname{OS} 2 a$ & $0.401(2)$ & $0.786(2)$ & $0.7078(5)$ & $0.10(7)$ \\
\hline $\operatorname{Os} 2 b$ & $0.730(5)$ & $0.470(2)$ & $0.225(1)$ & $0.07(1)$ \\
\hline $\operatorname{OS} 2 \mathrm{c}$ & $0.728(5)$ & $0.399(5)$ & $0.229(2)$ & $0.12(3)$ \\
\hline OS $3 a$ & $0.046(5)$ & $0.126(3)$ & $0.131(1)$ & $0.08(1)^{*}$ \\
\hline $0 \$ 3 b$ & $0.113(3)$ & $0.078(4)$ & $0.184(1)$ & $0.18(1)^{*}$ \\
\hline $\operatorname{OS} 3 \mathrm{c}$ & $0.045(5)$ & $0.042(6)$ & $0.113(1)$ & $0.13(2)^{*}$ \\
\hline OS4a & $1 / 3$ & $2 / 3$ & $0.2650(5)$ & $0.093(6)$ \\
\hline OS4b & $0.396(2)$ & $0.789(1)$ & $0.3390(3)$ & $0.053(2)$ \\
\hline $\operatorname{OS} 5 a$ & $1 / 3$ & $2 / 3$ & $0.5433(4)$ & $0.058(4)$ \\
\hline $0 \mathrm{Sb} \mathrm{b}$ & $0.397(1)$ & $0.791(1)$ & $0.4698(3)$ & $0.042(2)$ \\
\hline
\end{tabular}


TABLE 3. SELECTED BOND-DISTANCES ( $\AA$ ) FOR THE OXYGEN ATOMS OF THE FRAMEWORK OF FRANZINITE

\begin{tabular}{|c|c|c|c|c|c|c|c|c|}
\hline \multirow[t]{4}{*}{ Sil } & -01 & $1.57(2) \AA$ & $\mathrm{Si} 2$ & -09 & $1.58(1) \AA$ & $\mathrm{Si} 3$ & -05 & $1.62(1) \AA$ \\
\hline & -08 & $1.61(1) \AA$ & & -013 & $1.59(2) \AA$ & & -07 & $1.63(1) \AA$ \\
\hline & -011 & $1.57(1) \AA$ & & -016 & $1.58(1) \AA$ & & -010 & $1.60(1) \AA$ \\
\hline & -019 & $1.61(2) \AA$ & & -018 & $1.56(1) \AA$ & & -014 & $1.58(1) \AA$ \\
\hline \multirow[t]{4}{*}{ All } & -01 & $1.71(2) \AA$ & $\mathrm{Al} 2$ & -08 & $1.72(1) \AA$ & $\mathrm{Al} 3$ & .04 & $1.73(1) \AA$ \\
\hline & -09 & $1.71(1) \AA$ & & $-\mathrm{O} 13$ & $1.72(2) \AA$ & & -06 & $1.72(1) \AA$ \\
\hline & $-\mathrm{O} 12$ & $1.72(1) \AA$ & & $-\mathrm{O} 15$ & $1.74(1) \AA$ & & -010 & $1.74(1) \AA$ \\
\hline & -019 & $1.68(2) \AA$ & & -018 & $1.77(1) \AA$ & & -014 & $1.76(1) \AA$ \\
\hline \multirow[t]{4}{*}{$\mathrm{Si} 4$} & -012 & $1.55(1) \AA$ & $\mathrm{Si} 5$ & $-\mathrm{O} 2$ & $1.67(1) \AA$ & Si6 & -03 & $1.58(1) \AA$ \\
\hline & -012 & $1.55(1) \AA$ & & $-\mathrm{O} 4$ & $1.59(1) \AA$ & & -03 & $1.58(1) \AA$ \\
\hline & $-\mathrm{O} 20$ & $1.58(2) \AA$ & & -015 & $1.61(1) \AA$ & & -06 & $1.64(1) \AA$ \\
\hline & $-\mathrm{O} 20$ & $1.58(2) \AA$ & & -017 & $1.63(1) \AA$ & & -06 & $1.64(1) \AA$ \\
\hline \multirow[t]{4}{*}{ Al4 } & -011 & $1.70(1) \AA$ & Al5 & $-\mathrm{O} 2$ & $1.66(1) \AA$ & $\mathrm{Al} 6$ & -03 & $1.74(1) \AA$ \\
\hline & -011 & $1.70(1) \AA$ & & -05 & $1.75(1) \AA$ & & -03 & $1.74(1) \AA$ \\
\hline & $-\mathrm{O} 20$ & $1.69(2) \AA$ & & -016 & $1.72(1) \AA$ & & -07 & $1.75(1) \AA$ \\
\hline & $-\mathrm{O} 20$ & $1.69(2) \AA$ & & -017 & $1.69(1) \AA$ & & -07 & $1.75(1) \AA$ \\
\hline \multirow[t]{2}{*}{$\mathrm{A} 1$} & -013 & $2.57(1) \AA \AA \times 3$ & $\mathrm{~A} 2$ & -03 & $2.71(1) \AA \times 3$ & & & \\
\hline & -018 & $2.68(1) \AA \times 3$ & & -03 & $2.77(1) \AA \times 3$ & & & \\
\hline \multirow[t]{2}{*}{ A3 } & $-\mathrm{O} 2$ & $2.83(1) \AA \AA \times 3$ & $\mathrm{~A} 3 \mathrm{a}$ & $-\mathrm{O} 2$ & $2.97(1) \AA \times 3$ & $\mathrm{~A} 3 \mathrm{~b}$ & $-\mathrm{O} 2$ & $2.84(1) \AA \times 3$ \\
\hline & -017 & $2.51(1) \AA \times 3$ & & -017 & $2.75(1) \AA \times 3$ & & -017 & $2.44(1) \AA$ x 3 \\
\hline \multirow[t]{2}{*}{ A4 } & -020 & $2.66(1) \AA \times 3$ & $\mathrm{~A} 4 \mathrm{a}$ & $-\mathrm{O} 20$ & 2.62(1) $\AA$ x 6 & A5 & -010 & $2.47(1) \AA \times 3$ \\
\hline & $-\mathrm{O} 20$ & 2.84(1) $\AA \times 3$ & & & & & -014 & $2.90(1) \AA \times 3$ \\
\hline \multirow[t]{2}{*}{ A6 } & -01 & $2.70(1) \AA \times 3$ & A6a & -01 & $2.58(1) \AA \times 3$ & & & \\
\hline & -019 & $2.85(1) \AA \times 3$ & & -019 & $3.06(1) \AA \times 3$ & & & \\
\hline \multirow[t]{5}{*}{ M1 } & -011 & $2.64(2) \AA \times 2$ & M1a & -011 & $2.82(4) \AA$ & & & \\
\hline & -012 & $2.71(3) \AA \times 2$ & & -012 & $2.78(4) \AA$ & & & \\
\hline & -019 & $2.48(1) \AA \times x 2$ & & -012 & $2.96(4) \AA$ & & & \\
\hline & & & & -019 & $2.69(1) \AA$ & & & \\
\hline & & & & -019 & $2.75(2) \AA$ & & & \\
\hline \multirow[t]{6}{*}{ M2 } & -04 & $2.87(1) \AA$ & M3 & -04 & $2.58(1) \AA$ & M4 & -06 & $2.49(1) \AA \times 2$ \\
\hline & -05 & $2.79(1) \AA$ & & -05 & $2.61(1) \AA$ & & -07 & $2.46(1) \AA \times 2$ \\
\hline & .06 & 2.91(1) $\AA$ & & -013 & $2.88(1) \AA$ & & -014 & $2.95(1) \AA \times 2$ \\
\hline & -07 & $2.97(1) \AA$ & & -014 & $2.70(1) \AA$ & & & \\
\hline & & & & -015 & $2.46(1) \AA$ & & & \\
\hline & & & & -016 & $2.65(2) \AA$ & & & \\
\hline \multirow[t]{6}{*}{ M5 } & -08 & 2.71(2) $\AA$ & M5a & -09 & $2.86(3) \AA$ & M5b & -08 & $2.69(3) \AA$ \\
\hline & -09 & $2.65(2) \AA$ & & -011 & $2.82(3) \AA$ & & -09 & $2.84(3) \AA$ \\
\hline & -011 & $2.66(2) \AA$ & & -012 & $2.59(3) \AA$ & & -011 & $2.86(3) \AA$ \\
\hline & -012 & $2.69(3) \AA$ & & -018 & $2.67(2) \AA$ & & -018 & $2.83(2) \AA$ \\
\hline & -018 & $2.57(1) \AA$ & & -020 & $2.81(2) \AA$ & & -020 & $2.72(2) \AA$ \\
\hline & $-\mathrm{O} 20$ & $2.57(1) \AA$ & & & & & & \\
\hline \multirow[t]{6}{*}{ M5c } & -08 & $2.81(5) \AA$ & M6 & -01 & $2.82(1) \AA$ & M6a & -01 & $2.97(2) \AA$ \\
\hline & -09 & $2.65(4) \AA$ & & $-\mathrm{O} 2$ & $2.50(1) \AA$ & & $-\mathrm{O} 2$ & $2.85(2) \AA$ \\
\hline & -011 & $2.66(4) \AA$ & & -08 & $2.44(2) \AA$ & & -08 & $2.84(3) \AA$ \\
\hline & -012 & $2.62(5) \AA$ & & -09 & $2.59(2) \AA$ & & -015 & $2.78(3) \AA$ \\
\hline & -018 & $2.47(3) \AA$ & & -015 & $2.74(2) \AA$ & & -016 & $2.93(3) \AA$ \\
\hline & -020 & $2.64(3) \AA$ & & -016 & $2.68(2) \AA$ & & & \\
\hline \multirow[t]{6}{*}{ M6b } & -01 & $2.87(2) \AA$ & M6c & -01 & $2.95(2) \AA$ & & & \\
\hline & -02 & $2.74(2) \AA$ & & -02 & $2.53(2) \AA$ & & & \\
\hline & -08 & $2.49(2) \AA$ & & -08 & $2.62(3) \AA$ & & & \\
\hline & -09 & $2.44(3) \AA$ & & -09 & $2.91(3) \AA$ & & & \\
\hline & -016 & $2.83(2) \AA$ & & -015 & $2.58(3) \AA$ & & & \\
\hline & & & & -016 & $2.75(3) \AA$ & & & \\
\hline
\end{tabular}

The refined $T-\mathrm{O}$ bond distances confirm an ordered $\mathrm{Si}, \mathrm{Al}$ distribution. In fact, the average $\mathrm{Si}-\mathrm{O}$ bond distance is $1.60(3) \AA$, whereas the average $\mathrm{Al}-\mathrm{O}$ bond dis- tance is $1.72(3) \AA$ with a $d_{\mathrm{Si}-\mathrm{O}} / d_{\mathrm{Al}-\mathrm{O}}$ ratio of 0.93 (the values in brackets represent the actual dispersion of the $T-\mathrm{O}$ bond distances from their averaged values). 

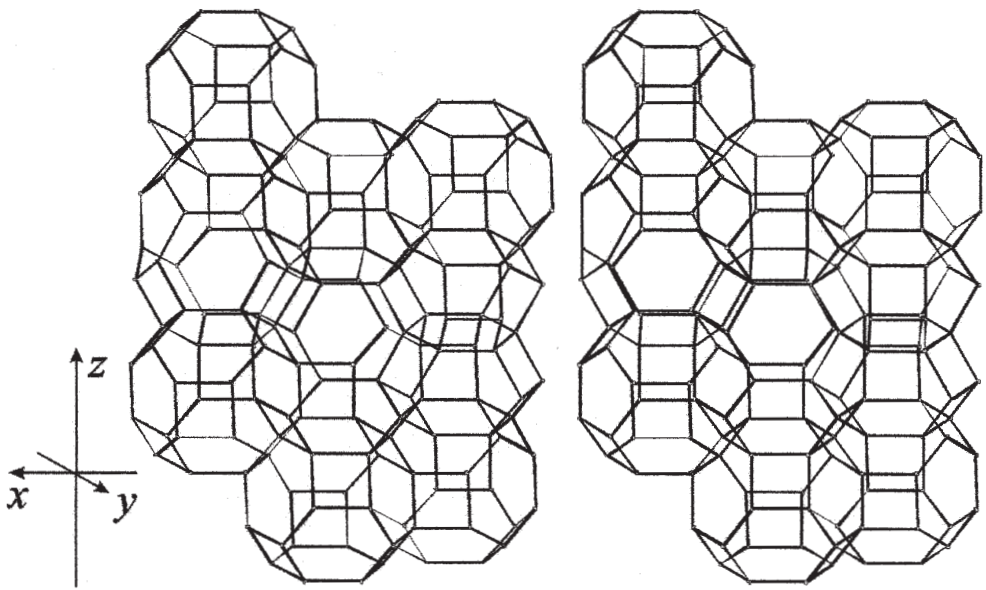

FIG. 2. Stereoplot of the framework of franzinite.

Because of the great complexity of the structure, we will describe separately the individual features of the various cages that constitute the franzinite structure.

TABLE 4. POPLLATION OF TITE FXTRAFRAMEWORK SITLS (A AND M) IN TRANZINITE

\begin{tabular}{|c|c|c|c|c|c|c|}
\hline Site & $\begin{array}{c}\text { Refined } \\
\text { occupanc } \\
y\end{array}$ & $\begin{array}{l}\% \\
\mathrm{Na} \\
(\%)\end{array}$ & $\begin{array}{c}\% \\
\mathrm{~K}, \mathrm{Ca} \\
\left({ }^{*}\right)\end{array}$ & $\underset{\mathrm{Nat}}{\mathrm{atans}}$ & $\begin{array}{l}\text { atoms } \\
\text { ( } \mathrm{K} . \mathrm{Ca})\end{array}$ & $\begin{array}{c}\text { atoms } \\
\mathrm{Ca} \\
(* *)\end{array}$ \\
\hline $\mathrm{Al}$ & 1 & 0 & 100 & - & - & 2.00 \\
\hline $\mathrm{A} 2$ & 0.50 & 100 & 0 & 1.00 & - & - \\
\hline A3 3 & 0.36 & & & & & \\
\hline$\triangle 3 \mathrm{a}$ & 0.18 & 53 & 47 & 1.06 & - & 0.94 \\
\hline$\Lambda 3 b$ & 0.22 & & & & & \\
\hline 14 & 0.27 & 89 & 11 & 0.89 & - & 0.11 \\
\hline A4a & 0.07 & 89 & & & & \\
\hline A5 & 1 & 0 & 100 & - & - & 2.00 \\
\hline 16 & 0.37 & 83 & 17 & 1.66 & 0.34 & - \\
\hline M1 & 0.42 & & & & & \\
\hline Mla & 0.14 & 56 & 34 & 1.98 & 1.02 & - \\
\hline $\mathrm{M} 2$ & 0.91 & 19 & 81 & 1.14 & 4.86 & - \\
\hline M3 & 0.66 & 76 & 24 & 4.56 & - & 1.44 \\
\hline M4 & 0.81 & 42 & 58 & 1.26 & - & 1.74 \\
\hline M5 & 0.29 & & & & & \\
\hline M5a & 0.12 & 72 & 28 & 4.32 & - & 1.68 \\
\hline M5b & 0.15 & & & & & \\
\hline $\begin{array}{l}\text { M5c } \\
\text { M6 }\end{array}$ & $\begin{array}{l}0.11 \\
0.33\end{array}$ & & & & & \\
\hline M6a & 0.15 & 600 & 40 & 3.60 & 2.40 & - \\
\hline Mob & 0.13 & & & & & \\
\hline M6c & 0.12 & & & & & \\
\hline$\Sigma_{\text {ditalith }}$ & & & & 21.47 & 8.62 & 9.91 \\
\hline
\end{tabular}

(*) These values were calculated assuming that, actually, each group of sites is fully occupied. For example, the total occupancy of the sites $A 3, \mathrm{~A} 3 \mathrm{a}, \mathrm{A} 3 \mathrm{~b}$, refined on the basis of the scattering power of $\mathrm{Ca}$, is 0.76 . A full occupancy would require the presence of only 15.2 electrons. which corresponds to $53 \% \mathrm{Na}$ and $47 \% \mathrm{Ca}$ (we include also $\mathrm{K}$. which has almost the same scattering power of $\mathrm{Ca}$ ).

(**) In some cases it was possible to discriminate between $\mathrm{Ca}$ and $(\mathrm{K}, \mathrm{CH})$ cations, on the basis of the observed distances with the oxygen atoms.

\section{“Losod” CAges}

The two symmetry-equivalent "losod" (17-hedra) cages are located along $\left[\begin{array}{lll}2 / 3 & 1 / 3 & z\end{array}\right]$ and $\left[\begin{array}{l}1 / 3 \\ 2 / 3\end{array}\right]$, respectively (Fig. 4). Each cage hosts two sulfate groups (S4 and S5), which are separated by a triplet of symmetry-equivalent $M 2$ cations. The $M 2$ cations mostly consist of $\mathrm{K}, \mathrm{Ca}(81 \% \mathrm{~K}, \mathrm{Ca} ; 19 \% \mathrm{Na})$. Two further triplets of cations $M 3$ and $M 4$ are located, respectively, around the S4 and S5 sulfate groups. M3 is dominantly occupied by $\mathrm{Na}$ atoms $(76 \% \mathrm{Na} ; 24 \%$ $\mathrm{K}, \mathrm{Ca}$ ), whereas the $M 4$ site has a $58 \% \mathrm{~K}, \mathrm{Ca}$ and a $42 \%$ $\mathrm{Na}$ occupancy. On the basis of the cation-oxygen distances, we may assume a distribution of cations similar to that of davyne (Bonaccorsi et al. 1990), with the "internal" site $M 2$ mainly occupied by $\mathrm{K}$ and the "external" sites $M 3$ and $M 4$ mainly occupied by $\mathrm{Na}$ and $\mathrm{Ca}$ atoms (Table 4).

The $A 1$ and $A 5$ cations occupy the bases of the cage and, according to the refined distribution of electron density and the cation-oxygen distances, they are calcium atoms. The two sulfur atoms are located on the triad axis and are bonded to two triplets of oxygen atoms, OS4b and OS5b, respectively, and to two apical atoms of oxygen, OS4a and OS5a, respectively. The bond distances are very similar and range from 1.46(1) to $1.47(1) \AA$. This type of sulfate coordination is allowed by the position of the calcium cations $A 1$ and $A 5$, which occur at favorable distances with the corresponding apical atoms of oxygen of the two sulfate groups [A1-OS4a $=2.23(1) \AA ; A 5-\mathrm{OS} 5 \mathrm{a}=2.21(1) \AA]$. There are some differences with respect to the distribution of cations and anions of the "losod" cage of liottite. In fact, the sulfate groups of that cage are disordered in liottite, because one of the calcium atoms located near the bases of the "losod" cage is distributed between two neighboring sites. Moreover, there are differences also with respect to the distribution of cations. 


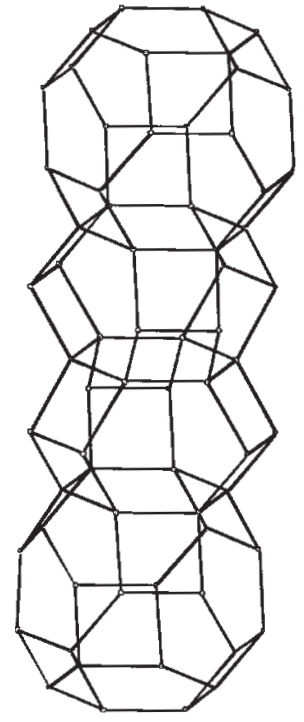

(a)

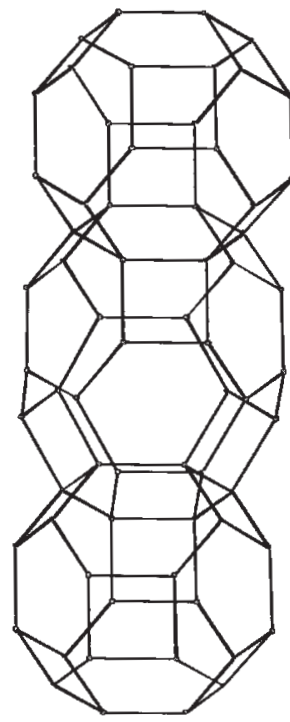

(b)
FIG. 3. (a) Superposition of the two "cancrinite" and two "sodalite" cages along $\left[\begin{array}{lll}0 & 0 & z\end{array}\right]$; (b) superposition of two "sodalite" and one "losod" cages along $[2 / 31 / 3 z]$ and $[1 / 32 / 3 z]$.

\section{"Sodalite" Cages}

The "sodalite" (cubo-octahedra) cages contain one sulfate group, which is strongly disordered; according to the extremely high $\mathrm{U}_{11}$ and $\mathrm{U}_{22}$ displacement parameters, the sulfur atoms seem to be displaced from the three-fold axis. Generally speaking, the cations are distributed among four different horizontal planes (Fig. 5): $(a)$ and $(b)$ planes are located in correspondence of the two bases of the cage; $(c)$ and $(d)$ are planes that bisect the six-membered rings of the lateral walls of the cage. Furthermore, each one of these planes presents multiple splitting of sites. Because of the complexity of the distribution of anions and cations, each one of the three independent "sodalite" cages will be described in turn. The identification number of the various cages refers to the label of the corresponding sulfur atom contained in the "sodalite" cage (example: "sodalite" cage 1 refers to the cage that contains S1).

\section{"Sodalite” cage 1}

The "sodalite" cage 1 shares its bases with a "losod" cage and with the "sodalite" cage 2 . Three partially occupied triplets of oxygen atoms (OS1a, OS1b, and OS1c, respectively) set up the coordination of the sulfate group (in Fig. 6a, only one of the three possible orientations of the sulfate tetrahedron is shown). The

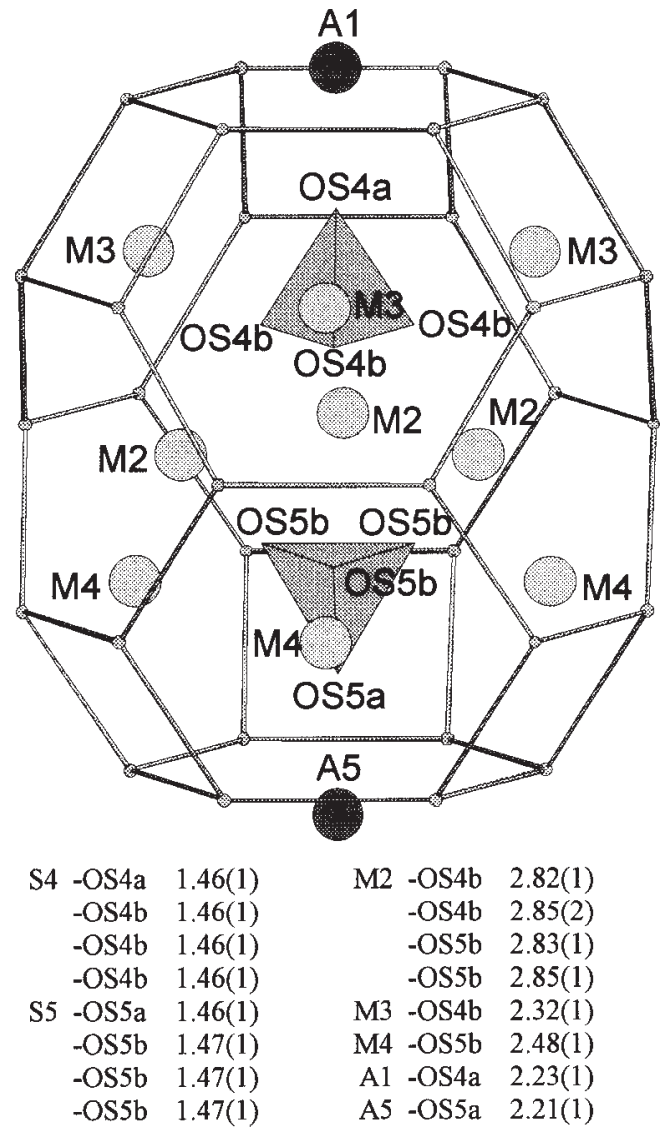

FIG. 4. The "losod" cage and its content. The relevant bonddistances among the extra-framework cations and anions also are reported.

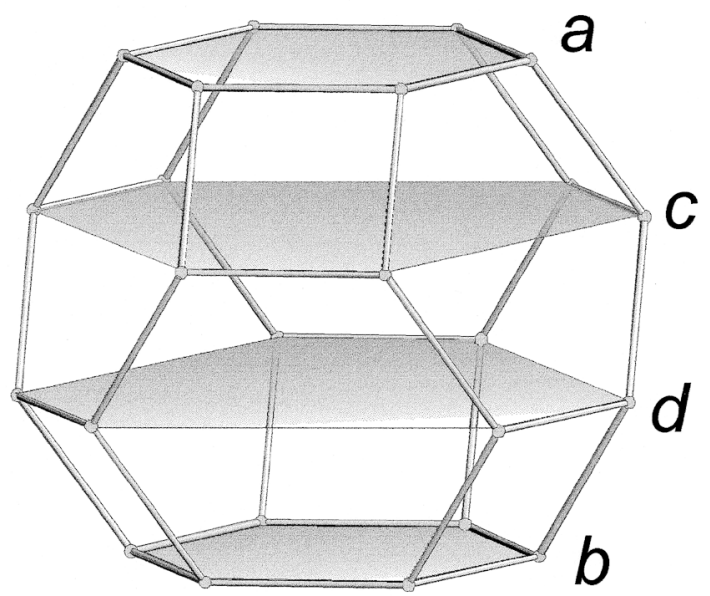

FIG. 5. Within the "sodalite" cages, the cationic sites are located on four different levels, indicated with the letters $a$, $b, c$, and $d$. 

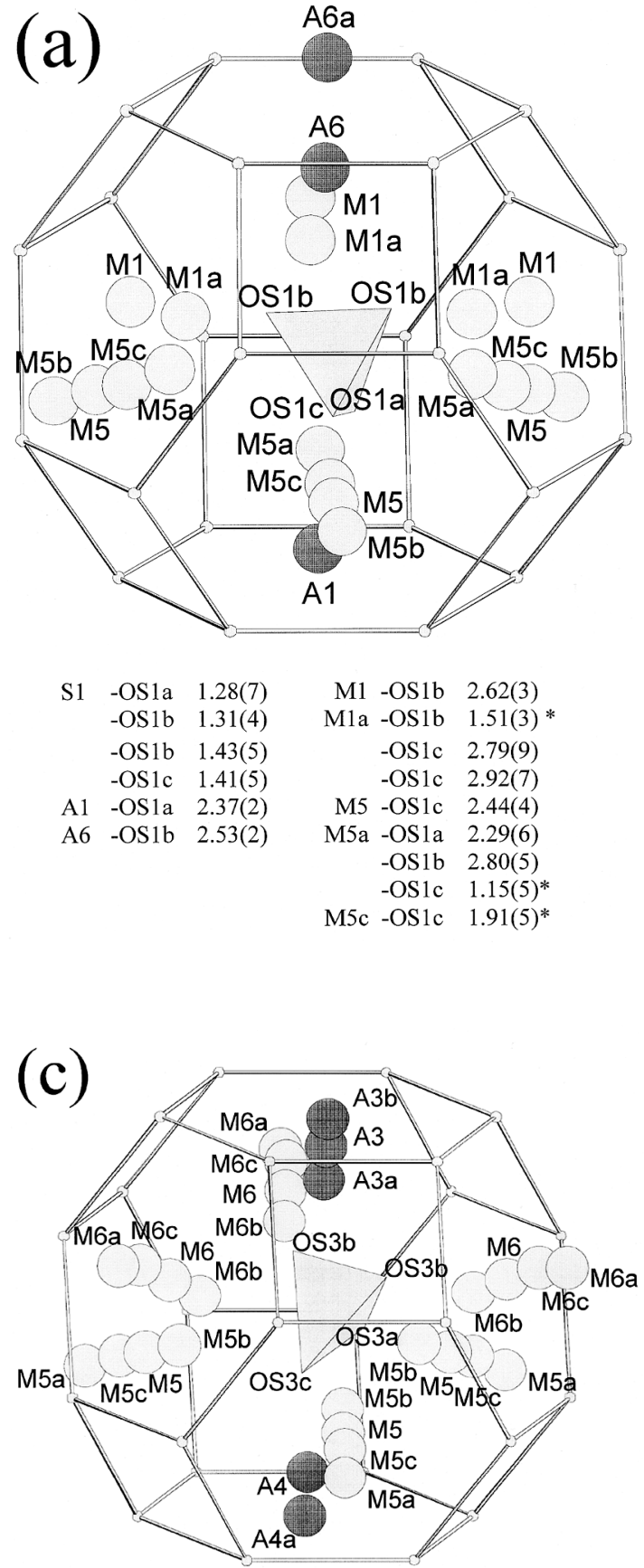

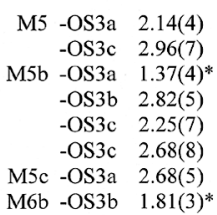

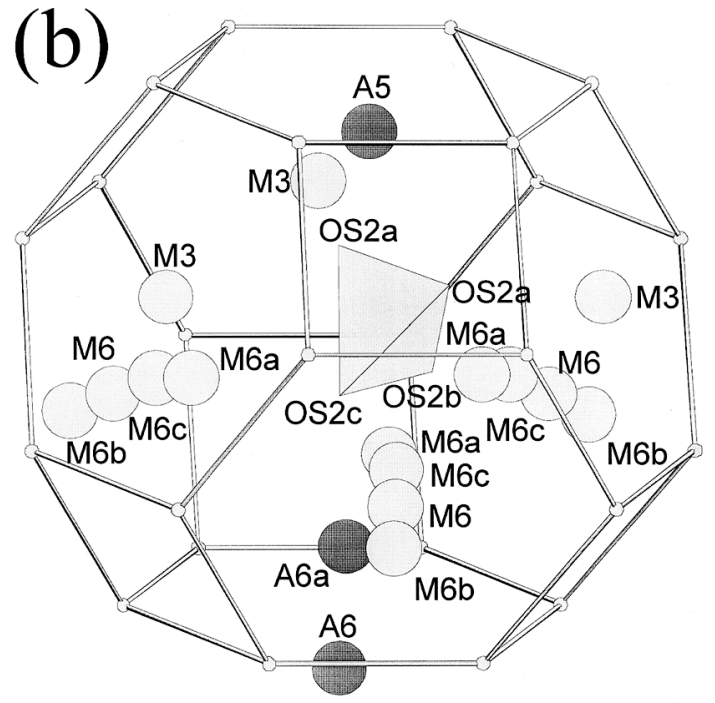

$\begin{array}{lll}\text { S2 } & -O S 2 a & 1.28(2) \\ & -O S 2 a & 1.74(3) \\ & -O S 2 b & 1.51(4) \\ & -O S 2 c & 1.50(5) \\ \text { A5 } & -O S 2 a & 2.54(1) \\ \text { A6a } & - \text { OS2b } & 2.87(4) \\ & -O S 2 c & 2.67(6)\end{array}$

$\begin{array}{rll}\text { M3 } & -O S 2 a & 2.67(2) \\ \text { M6 } & -O S 2 b & 2.29(3) \\ \text { M6a } & -O S 2 a & 2.90(3) \\ -O S 2 b & 0.99(3)^{*} \\ \text {-OS2c } & 1.84(6)^{*} \\ \text {-OS2c } & 2.67(6) \\ \text { M6c } & -O S 2 b & 1.55(3)^{*} \\ -O S 2 c & 2.39(6)\end{array}$

FIG. 6. The three different types of "sodalite" cages of franzinite: (a) "sodalite" cage 1, (b) "sodalite" cage 2, and (c) "sodalite" cage 3. For each cage, the relevant bonddistances among the extra-framework cations and anions are reported. The very short $M-\mathrm{O}$ distances marked with a star do not actually occur, as explained in the text.

individual $\mathrm{S}-\mathrm{O}$ bond distances show quite a spread [mean value 1.36(6) $\AA$ ], this fact being due to the difficulty to locate the actual position of the oxygen atoms. The cation sites in the $(a)$ and $(b)$ planes are occupied, respectively, by $A 1$ and $A 6-A 6$ a. The calcium atom $A 1$ makes a bond distance of 2.37(2) $\AA$ with the neighboring OS1a atom. On the other side of the cage, two partially occupied cation sites are observed (A6 and A6a) whose total electron density is consistent with an occupancy by $83 \% \mathrm{Na}$ and $17 \% \mathrm{~K}, \mathrm{Ca}$. The two $A 6$ and $A 6 \mathrm{a}$ sites are 1.87(2) $\AA$ away each other and, whereas $A 6$ makes typical bond-distances with the oxygen atoms of the $\mathrm{S} 1$ sulfate group, A6a is displaced toward "sodalite" cage 2. A couple of split cation-sites $M 1$ and $M 1 \mathrm{a}$ are present at level $(c)$; according to their total refined electron-density, they are occupied by $66 \% \mathrm{Na}$ and 
$34 \%$ K,Ca. Four further sites $M 5, M 5 \mathrm{a}, M 5 \mathrm{~b}$, and $M 5 \mathrm{c}$ are located on the plane $(d)$. Sites M5, M5a, and M5c are within the cage 1 , whereas $M 5 \mathrm{~b}$ is displaced toward the neighboring "sodalite" cage 3 . The refined electrondensity and the observed distances from the oxygen atoms are compatible with an occupancy of $72 \% \mathrm{Na}$ and $28 \% \mathrm{Ca}$ for these sites (Table 4 ).

As a general remark, some of the bond distances between cation sites and oxygen atoms of the sulfate groups are unacceptably short, which means that a simultaneous occupancy of the cation and oxygen sites does not actually occur (Figs. 6a, b, c).

"Sodalite" cage 2

This cage shares its bases with a "losod" cage and with the "sodalite" cage 1 . Three triplets of oxygen atoms (OS2a, OS2b, and OS2c, respectively) occur within the cage, each one with partial occupancy. One of the three resulting symmetry-related $\mathrm{SO}_{4}$ tetrahedra is shown in Figure 6b. As in "sodalite" cage 1, the S-O bond distances show a broad range. On the $(a)$ and $(b)$ planes there are, respectively, the $A 5$ calcium cation and the $A 6-A 6$ a split sites already described in descriptions of "sodalite" cage 1 .

The triplet of $M 3$ cations is located exactly at the center of three hexagonal rings of $\mathrm{TO}_{4}$ tetrahedra (shared with the "losod" cage) in correspondence of the $(c)$ plane. As previously indicated, the chemical content of the $M 3$ site, on the basis of the refined electron-density and of the M3-O distances, is $76 \% \mathrm{Na}$ and $24 \% \mathrm{Ca}$.

Four further split sites are present on plane $(d), M 6$, $M 6 \mathrm{a}, M 6 \mathrm{~b}$, and $M 6 \mathrm{c}$, which show a $60 \% \mathrm{Na}$ and a $40 \%$ $\mathrm{K}, \mathrm{Ca}$ occupancy. $M 6$ atoms are located at the center of the hexagonal rings, whereas $M 6 \mathrm{a}$ and $M 6 \mathrm{c}$ are displaced toward the center of "sodalite" cage 2, and M6b, toward the neighboring "sodalite" cage 3 .

\section{"Sodalite" cage 3}

The two symmetry-related "sodalite" cages 3 share one base, the other base being shared with a superimposed "cancrinite" cage. The $\mathrm{SO}_{4}$ polyhedron is distorted, and is placed off-axis (Fig. 6c). On the two bases of the cage we find, respectively, a triplet ( $A 3, A 3 \mathrm{a}$, and $A 3 \mathrm{~b})$ and a pair ( $A 4$ and $A 4 \mathrm{a})$ of electron-density maxima. The sites $A 3, A 3 \mathrm{a}$, and $A 3 \mathrm{~b}$ contain $53 \% \mathrm{Na}$ and $47 \% \mathrm{~K}, \mathrm{Ca}$, whereas the $A 4$ and $A 4 \mathrm{a}$ sites are mostly occupied by $\mathrm{Na}(89 \% \mathrm{Na}$ and $11 \% \mathrm{~K}, \mathrm{Ca})$. In both sites, the occurrence of short cation-oxygen distances [for example, $A 3 \mathrm{a}-\mathrm{OS} 3 \mathrm{~b}$ at $2.22(3) \AA$ and $A 4-\mathrm{OS} 3 \mathrm{c}$ at 2.22(4) $\AA$ ] suggests that the sites cannot be occupied by potassium cations, and that their actual chemical content is $53 \% \mathrm{Na}, 47 \% \mathrm{Ca}$ and $89 \% \mathrm{Na}, 11 \% \mathrm{Ca}$, respectively. The four $M 5$ sites (shared with the "sodalite" cage 1) and the four M6 sites (shared with the "sodalite" cage $2)$ occupy the planes $(c)$ and $(d)$.
During the isotropic refinement, we made an attempt to refine the occupancy of the oxygen sites of the sulfate groups in the various "sodalite" cages. The occupancies of the oxygen sites of sulfate groups S1 and S2 are consistent with the required geometry of the polyhedra, whereas sulfate group S3 did not show an adequate value of the electron density compatible with the presence of four oxygen atoms around the corresponding sulfur atom (only $3 / 4$ of the oxygen atoms seem to be present). On the other side, the sulfur site is fully occupied (actually S3 is slightly displaced from the special position at $0,0, z$, and statistically occupies one of the three symmetry-related positions). Three possible interpretations may be proposed: a) an error in the calculated electron-density may be due to the correlation existing between the thermal parameter and the corresponding occupancy, b) a partial replacement of $\left(\mathrm{SO}_{4}\right)^{2-}$ by $\mathrm{Cl}^{-}$occurs, as in sodalite; this hypothesis seems to be in contradiction with the chemical data, which do not reveal any deficiency in sulfur content, or c) a partial replacement of $\left(\mathrm{SO}_{4}\right)^{2-}$ by $\mathrm{S}^{2-}$ occurs, as in lazurite, a member of the related sodalite-group minerals (Hassan et al. 1985).

No strong support of any one of these hypotheses has been found; therefore, we preferred to continue the refinement considering the "sodalite" cage 3 as fully occupied by one $\left(\mathrm{SO}_{4}\right)^{2-}$ group, despite the real or apparent deficiency in oxygen.

The "sodalite" cages of lazurite (Hassan et al. 1985) and nosean (Hassan \& Grundy 1989) show features similar to those just described for the "sodalite" cage of franzinite. The cations are distributed among the four $(a),(b),(c)$, and $(d)$ planes, and they show multiple splitting of sites; however, the occupancy of one of the split sites is incompatible with the presence inside the cage of one $\left(\mathrm{SO}_{4}\right)^{2-}$ group. This fact has been explained as due to either $\mathrm{S}^{2-}$ or $\mathrm{H}_{2} \mathrm{O}$ versus $\left(\mathrm{SO}_{4}\right)^{2-}$ partial substitutions. The corresponding frameworks are distorted because the different content of anions is reflected in the relative dimensions of the cages. In the case of nosean (Hassan \& Grundy 1989), the mineral has an average structure that results from the presence of two distinct structures, respectively with a cubic cell edge of $8.9 \AA$ (nosean containing $\mathrm{H}_{2} \mathrm{O}$ only), and a cubic cell edge of $9.2 \AA$ [nosean containing only $\left(\mathrm{SO}_{4}\right)^{2-}$ ]. The same situation is found in lazurite (Hassan et al. 1985), owing to the occurrence of $\mathrm{S}^{2-}$-bearing and $\left(\mathrm{SO}_{4}\right)^{2-}$-bearing cages. As a matter of fact, "sodalite" cage 3 has an extremely disordered distribution (A3-A3a-A3b; A4-A4a; M5-M5a-M5b-M5c; M6$M 6 \mathrm{a}-M 6 \mathrm{~b}-M 6 \mathrm{c})$, which is coupled with an apparent deficiency of oxygen atoms of the sulfate group. On the basis of the preceding discussion, this situation seems to be compatible with a partial $\mathrm{S}^{2-} \Leftrightarrow\left(\mathrm{SO}_{4}\right)^{2-}$ substitution. 


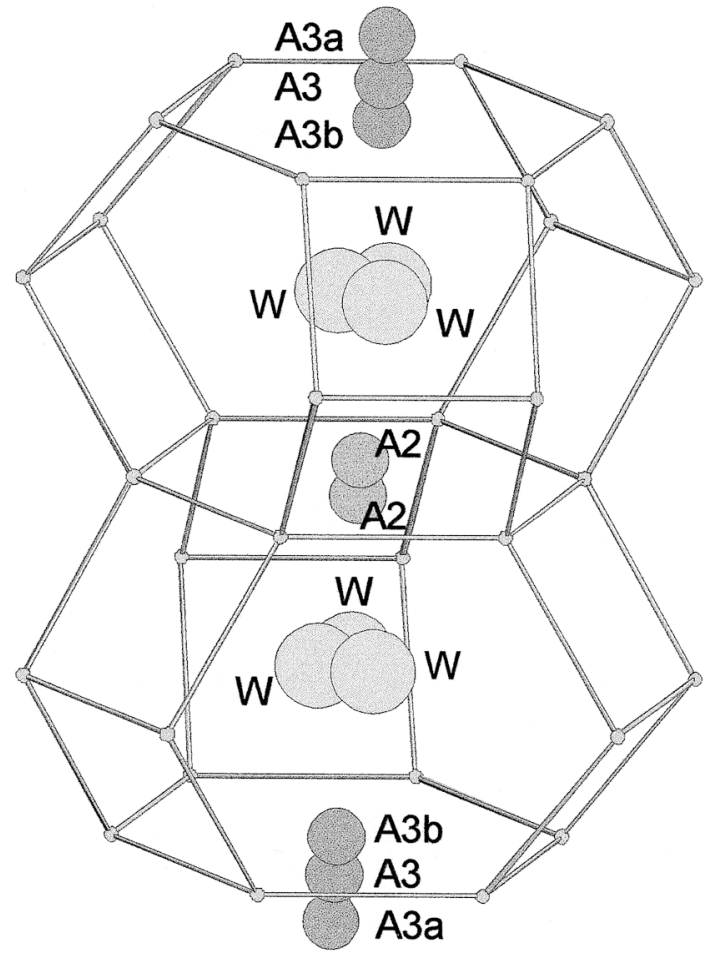

$\begin{array}{rrrrr}\mathrm{W} & -\mathrm{A} 2 & 2.53(7) & \mathrm{W}-\mathrm{A} 2 & 3.07(7) \\ & -\mathrm{A} 3 & 3.15(3) & -\mathrm{A} 3 \mathrm{~b} & 2.61(3)\end{array}$

FIG. 7. The two superimposed "cancrinite" cages and their content. Bond distances between the $\mathrm{H}_{2} \mathrm{O}$ molecules $W$ and the neighboring cations also are reported.

\section{CAnCRinite CAges}

The two symmetry-equivalent "cancrinite" cages share a common base, the other base being shared with the "sodalite" cage 3. Each "cancrinite" cage contains a molecule of $\mathrm{H}_{2} \mathrm{O}$ that is statistically disordered over three symmetry-related positions (Fig. 7). The $\mathrm{Na}$ atom is not exactly located at the center of the common basis, but is slightly displaced $(A 2)$. This displacement from the special position $0,0,1 / 2$ leads to a disordered distribution of the $\mathrm{Na}$ atom into two equivalent half-occupied positions at $z \approx 0.49$ and $z \approx 0.51$. Owing to the very short distance between the two positions $(\sim 0.5 \AA)$, only one of them is actually occupied. The $\mathrm{H}_{2} \mathrm{O}$ molecule makes two different bond-distances with $A 2$ [2.53(7) and 3.07(7) $\AA]$, depending on which one of the two positions is occupied.

Three different electron-density maxima were observed near the center of the base shared with the "sodalite" cage 3 ( $A 3, A 3 \mathrm{a}$, and $A 3 \mathrm{~b})$, each one with partial occupancy. As previously pointed out, the sites
$A 3, A 3 \mathrm{a}$, and $A 3 \mathrm{~b}$ contain $53 \% \mathrm{Na}$ and $47 \% \mathrm{~K}, \mathrm{Ca}$. The $\mathrm{H}_{2} \mathrm{O}$ molecule makes two different bond-distances with $A 3 \mathrm{~b}[2.61(4) \AA]$ and $A 3$ [3.15(4) $\AA$ ], whereas $A 3 \mathrm{a}$ is displaced toward the neighboring "sodalite" cage 3 .

The structure refinements of carbonate-dominant cancrinite (Jarchow 1965, Smolin et al. 1981, Emiraliev \& Yamzin 1982, Grundy \& Hassan 1982), Ge-substituted cancrinite (Belokoneva et al. 1986), basic (i.e., hydroxyl-dominant) cancrinite (Bresciani Pahor et al. 1982, Hassan \& Grundy 1991), vishnevite (Hassan \& Grundy 1984, Pushcharovskii et al. 1989), pitiglianoite (Merlino et al. 1991), bystrite (Pobedimskaya et al. 1991a), and afghanite (Pobedimskaya et al. 1991b) have shown that the $\mathrm{H}_{2} \mathrm{O}$ molecule of the "cancrinite" cage has one short distance $(2.4 \AA)$ and one long distance $(2.9 \AA)$ to the cations. Accordingly, we propose that the short $W-A 2$ bond distance [2.53(7) $\AA$ ] is coupled with the occupancy of the $A 3$ site, leading to a long [3.15(4) $\AA] W-A 3$ bond distance. Conversely, the long $W-A 2$ bond distance $[3.07(7) \AA]$ may be coupled with the occupancy of the $A 3 \mathrm{~b}$ site $[W-A 3 \mathrm{~b}$ bond distance of 2.61(4) A]. The explanation of the occurrence of the $A 3 \mathrm{a}$ site is more difficult. If we consider the partial $\mathrm{S}^{2-} \Leftrightarrow$ $\left(\mathrm{SO}_{4}\right)^{2-}$ substitution into the "sodalite" cage 3 as a possibility, the occurrence of the $A 3 \mathrm{a}$ site could be related with the presence of $\mathrm{S}^{2-}$. In any case, $A 3 \mathrm{a}$ makes an acceptable bond-distance with the oxygen OS3b of the sulfate group of the "sodalite" cage 3 .

\section{Discussion}

The structure of franzinite has been refined to an $R$ value of $5.96 \%$ in the space group $P 321$. The stacking sequence is $A B C A B A C A B C$. The space group P321 allows an ordered distribution of $\mathrm{Si}$ and $\mathrm{Al}$ inside the framework, a pattern of order that is confirmed by the refined $\mathrm{Si}-\mathrm{O}[1.60(3) \AA]$ and $\mathrm{Al}-\mathrm{O}$ [1.72(3) $⿱$ $]$ bond distances. The result is in keeping with the $\mathrm{Si}$ :Al ratio, equal to 1 , as derived from the electron-microprobe data. According to the recent refinement of the structure of liottite (Ballirano et al. 1996a) and afghanite (Ballirano et al. 1997), which correspond to the 6- and 8-layer members, respectively, of the family of cancrinite-like minerals, an ordered $\mathrm{Si}, \mathrm{Al}$ distribution may be expected for the phases showing a 1:1 Si,Al compositional ratio. So far, only cancrisilite (Khomyakov et al. 1991) shows a significant deviation from the ideal 1:1 ratio. Three different types of cages are found in the franzinite structure: "cancrinite" cages, "sodalite" cages, and "losod" cages. Two "cancrinite" cages and two "sodalite" cages are stacked along $\left[\begin{array}{lll}0 & 0 & z\end{array}\right]$, whereas a "losod" cage and two "sodalite" cages repeat along $[2 / 31 / 3 z]$ and $[1 / 32 / 3 z]$. The "cancrinite" cage hosts a molecule of $\mathrm{H}_{2} \mathrm{O}$ that is displaced from the three-fold axis and disordered over three symmetry-related positions, forming a $\mathrm{Na}-\mathrm{H}_{2} \mathrm{O} \ldots \mathrm{Na}-\mathrm{H}_{2} \mathrm{O}$ sequence, similar to that found in many cancrinite-like minerals. Three distinct "sodalite" cages have been observed, differing in the extremely 
complex pattern of distribution of cations. The sulfate groups hosted by the cages are displaced off-axis. In the case of the "sodalite" cage 3, the geometry of the sulfate group does not seem complete because of an apparent lack of oxygen atoms. This fact has been tentatively attributed to a partial $\mathrm{S}^{2-} \Leftrightarrow\left(\mathrm{SO}_{4}\right)^{2-}$ substitution, as found in the related mineral lazurite. The "losod" cage contains two sulfate groups that are perfectly superimposed along $z$; it features a relatively simple distribution of cations, similar to that observed in the "losod" cage of liottite. From the structural refinement, a formula of $\left[\mathrm{Na}_{21.5}(\mathrm{Ca}, \mathrm{K})_{8.6} \mathrm{Ca}_{9.9}\left[\mathrm{Si}_{30} \mathrm{Al}_{30} \mathrm{O}_{120}\right]\left(\mathrm{SO}_{4}\right)_{10} \cdot 2 \mathrm{H}_{2} \mathrm{O}\right.$ was obtained (Table 4), which is in agreement with $\left[\mathrm{Na}_{20.5} \mathrm{~K}_{6.7} \mathrm{Ca}_{11.7}\left[\mathrm{Si}_{29.8} \mathrm{Al}_{30.2} \mathrm{O}_{119.7}\right]\left(\mathrm{SO}_{4}\right)_{10.0} \mathrm{Cl}_{0.3} \mathrm{~F}_{0.1} \bullet\right.$ $n \mathrm{H}_{2} \mathrm{O}$ derived from the results of the electron microprobe-analysis and IR spectroscopy. The ideal formula may be written as $\left[(\mathrm{Na}, \mathrm{K})_{30} \mathrm{Ca}_{10}\right]\left[\mathrm{Si}_{30} \mathrm{Al}_{30} \mathrm{O}_{120}\right]$ $\left(\mathrm{SO}_{4}\right)_{10} \cdot 2 \mathrm{H}_{2} \mathrm{O}$. In order to obey electroneutrality, 50 positive charges have to be supplied by the cations, and this value may only be obtained with the presence of ten calcium atoms; every calcium in excess may be balanced by a non-stoichiometric proportion of the cations or a partial substitution of the $\mathrm{H}_{2} \mathrm{O}$ molecules with $\mathrm{Cl}^{-}$and $\mathrm{F}^{-}$anions. The sample we studied contains 11.7 calcium atoms, and a nonstoichiometric proportion of the cations has been detected by means of the electronmicroprobe analysis, leading to a total of 39 cations instead of the maximum allowable number of 40 ; moreover, small amounts of $\mathrm{Cl}^{-}$and $\mathrm{F}^{-}$anions have been documented by electron-microprobe analysis.

\section{ACKNOWLEDGEMENTS}

The financial support from CNR and MURST is acknowledged. Thanks are due to S. Lucchesi for the help in acquisition of the single-crystal data. We thank also D. Pushcharovskii, R.F. Martin, and an anonymous referee for their useful suggestions.

\section{REFERENCES}

Ballirano, P., Maras, A. \& Buseck, P.R. (1996b): Crystal chemistry and IR spectroscopy of $\mathrm{Cl}$ - and $\mathrm{SO}_{4}$-bearing cancrinite-like minerals. Am. Mineral. 81, 1003-1012.

Caminiti, R. \& Sadun, C. (1995):

Carbonate-cancrinite: in-situ real-time thermal processes studied by means of energy-dispersive X-ray powderdiffractometry. Powder Diffraction 10, 173-177.

Merlino, S., Bonaccorsi, E. \& Maras, A. (1996a): The crystal structure of liottite, a six-layer member of the cancrinite group. Can. Mineral. 34, 1021-1030.

$$
\&
$$

(1997): Crystal

structure of afghanite, the eight-layer member of the cancrinite-group: evidences for long-range $\mathrm{Si}, \mathrm{Al}$ ordering. Eur. J. Mineral. 9, 21-31.
Belokoneva, E.L., Uvarova, T.G. \& Dem'yanets, L.N. (1986): Crystal structure of synthetic Ge- cancrinite $\mathrm{Na}_{8}\left[\mathrm{Al}_{6} \mathrm{Ge}_{6} \mathrm{O}_{24}\right] \mathrm{Ge}(\mathrm{OH})_{6} \cdot 2 \mathrm{H}_{2} \mathrm{O}$. Sov. Phys. Crystallogr. 31, 516-519.

Bonaccorsi, E., Merlino, S. \& Pasero, M. (1990): Davyne: its structural relationships with cancrinite and vishnevite. Neues Jahrb. Mineral., Monatsh., 97-112.

Bresciani Pahor, N., Calligaris, M., Nardin, G. \& RANDACCIO, L. (1982): Structure of a basic cancrinite. Acta Crystallogr. B38, 893-895.

Emiraliev, A. \& Yamzin, I.I. (1982): Neutron-diffraction refinement of the structure of carbonate- cancrinite. Sov. Phys. Crystallogr. 27, 27-30.

Franceschini, F. \& OrLANDI, P. (1989): Ritrovamento della franzinite in una perforazione geotermica dei Sabatini (Lazio). Rend. Soc. Ital. Mineral. Petrol. 43, 781-788.

GRUNDY, H.D. \& HASSAN, I. (1982): The crystal structure of a carbonate-rich cancrinite. Can. Mineral. 20, 239-251.

HASSAN, I. \& GRUNDY, H.D. (1984): The character of the cancrinite-vishnevite solid-solution series. Can. Mineral. 22, 333-340.

\& (1989): The structure of nosean, ideally $\mathrm{Na}_{8}\left(\overline{\left.\mathrm{Al}_{6} \mathrm{Si}_{6} \mathrm{O}_{24}\right)} \mathrm{SO}_{4} \bullet \mathrm{H}_{2} \mathrm{O}\right.$. Can. Mineral. 27, 165-172.

\& (1991): The crystal structure of basic cancrinite, ideally $\mathrm{Na}_{8}\left[\mathrm{Al}_{6} \mathrm{Si}_{6} \mathrm{O}_{24}\right](\mathrm{OH})_{2} \bullet 3 \mathrm{H}_{2} \mathrm{O}$. Can Mineral. 29, 377-383.

Peterson, R.C. \& GRUNDY, H.D. (1985): The structure of lazurite, ideally $\mathrm{Na}_{6} \mathrm{Ca}_{2}\left(\mathrm{Al}_{6} \mathrm{Si}_{6} \mathrm{O}_{24}\right) \mathrm{S}_{2}$, a member of the sodalite group. Acta Crystallogr. C41, 827-832.

JaRchow, O. (1965): Atomanordnung und Strukturverfeinerung von Cancrinit. Z. Kristallogr. 122, 407-442.

Khomyakov, A.P., Semenov, E.I., Pobedimskaya, E.A., NadeZhina, T.N. \& RastsvetaeVA, R.K. (1991): Cancrisilite, $\mathrm{Na}_{7}\left[\mathrm{Al}_{5} \mathrm{Si}_{7} \mathrm{O}_{24}\right] \mathrm{CO}_{3} \cdot 3 \mathrm{H}_{2} \mathrm{O}$ : a new mineral of the cancrinite group. Zap. Vser. Mineral. Obshchest. 120(6), 80-84 (in Russ.).

LeOni, L., Mellini, M., Merlino, S. \& Orlandi, P. (1979): Cancrinite-like minerals: new data and crystal chemical considerations. Rend. Soc. Ital. Mineral. Petrol. 35, 713-719.

MERLINO, S. (1976): Framework silicates. Izvj. Jugoslav. centr. kristalogr. (Zagreb) 11, 19-37.

\& Mellini, M. (1976): Crystal structures of cancrinite-like minerals. Zeolite '76 (Tucson), Program and Abstr., 47.

, Bonaccorsi, E., PAsero, M., LeONI, L. \& ORLANDI, P. (1991): Pitiglianoite, a new feldspathoid from southern Tuscany, Italy: chemical composition and crystal structure. Am. Mineral. 76, 2003-2008. 
\& ORLANDI, P. (1977): Franzinite, a new mineral phase from Pitigliano (Italy). Neues Jahrb. Mineral., Monatsh., 163-167.

Nakamoto, K., Margoshes, M. \& Rundle, R.E. (1955): Stretching frequencies as a function of distances in hydrogen bonds. J. Am. Chem. Soc. 77, 6480-6486.

Patterson, A.L. \& Kasper, J.S. (1959): Close packing. In International Tables for X-ray Crystallography II. The Kynoch Press, Birmingham, U.K. (342-354).

Pobedimskaya, E.A., Rastsvetaeva, R.K., Terentieva, L.E. \& SAPozhnikov, A.N. (1991b): Crystal structure of afghanite. Sov. Phys. Dokl. 36, 663-665.

Terentieva, L.E., SAPOZhnikov, A.N., Kasaev, A.A. \& Dorochova, G.I. (1991a): Crystal structure of bystrite. Sov. Phys. Dokl. 36, 553-556.
Pushcharovskit, D.Yu., Yamnova, N.A. \& Khomyakov, A.P. (1989): Crystal structure of high-potassium vishnevite. Sov. Phys. Crystallogr. 34, 37-39.

RINALDI, R. \& WENK, H.-R. (1979): Stacking variations in cancrinite minerals. Acta Crystallogr. A35, 825-828.

SHeLdRICK, G.M. (1993): SHELXL-93. Program for Crystal Structure Determination. Institut für Anorg. Chemie, Göttingen, Germany.

Smolin, Yu.I., Shepelev, Yu.F., Butikova, I.K. \& Kobyakov, I.B. (1981): Crystal structure of cancrinite. Sov. Phys. Crystallogr. 26, 33-35.

ZhDanov, G.S. (1945): The numerical symbol of close packing of spheres and its application in the theory of close packing. Compt. Rend. Acad. Sci. URSS 48, 39-42.

Received November 26, 1999, revised manuscript accepted April 15, 2000. 